\title{
Intersectional Stigma and Multi-Level Barriers to HIV Testing Among Foreign-Born Black Men From the Caribbean
}

\author{
Tonya N. Taylor*, Jack DeHovitz and Sabina Hirshfield \\ SUNY Downstate Health Sciences University, Brooklyn, NY, United States
}

Testing is the entry point into the HIV care continuum that includes linkage to and retention in prevention services, and adherence to prevention strategies, including repeat HIV testing. Despite US policy approaches to expand HIV testing to diverse clinical care and community settings, disparities in HIV testing among Black populations persist. Foreign-born (FB) Black persons from the Caribbean have higher annual rates of HIV diagnosis and a higher percentage of late-stage HIV diagnosis, compared with US-born Black persons; and most HIV infections among FB Blacks are among men. In this article, we provide an overview of HIV testing barriers among FB Black men who engage in HIV

OPEN ACCESS

Edited by:

Allison A. Appleton

University of North Carolina, Chapel

Hill, United States

Reviewed by:

Devon Price,

Hunter College (CUNY), United States

Tamar Goldenberg,

University of North Carolina at Chapel

Hill, United States

${ }^{*}$ Correspondence:

Tonya N. Taylor

Tonya.Taylor@downstate.edu

\section{Specialty section: \\ This article was submitted to Inequalities in Health, \\ a section of the journal \\ Frontiers in Public Health}

Received: 05 May 2019 Accepted: 21 November 2019

Published: 10 January 2020

Citation:

Taylor TN, DeHovitz J and Hirshfield S

(2020) Intersectional Stigma and

Multi-Level Barriers to HIV Testing Among Foreign-Born Black Men From

the Caribbean.

Front. Public Health 7:373. doi: 10.3389/fpubh.2019.00373 risk-taking behaviors (e.g., condomless sex with male and/or female partners of unknown HIV serostatus). Barriers to HIV testing for both FB and US-born Black men, include HIV stigma (anticipated, perceived, internalized), low perceived HIV risk, medical or government mistrust, and perceived low access to testing resources. We examine beliefs about masculinity and gender roles that may perpetuate heteronormative stereotypes associated with perceptions of low HIV risk and barriers to HIV testing. We also discuss the impact of recent immigration policies on accessing HIV testing and treatment services and how intersectional stigmas and structural forms of oppression, such as racism, prejudice against select immigrant groups, and homophobia that may further amplify barriers to HIV testing among FB Black men. Finally, we review comprehensive prevention approaches, and suggest innovative approaches, that may improve the uptake of HIV testing among FB Black men.

Keywords: intersectional stigma, foreign born, Caribbean men, HIV testing barriers, stigma-reducing interventions

\section{INTRODUCTION}

In the United States (US), foreign-born (FB) persons, defined as individuals who were born outside the continental US and its territories, and naturalized citizens, comprise only $13 \%$ of the country's population, yet FB individuals face barriers to accessing health care that may lead to poorer HIV disease outcomes $(1,2)$. FB persons account for $16 \%$ of new HIV infections in the US (2); however, FB Blacks from the Caribbean and Africa have higher annual rates of HIV diagnosis, and latestage HIV diagnosis, compared to US-born Blacks and FB Whites, thus highlighting disparities due to race and immigration status $(3,4)$. FB Black men who engage in HIV risk-taking behaviors, including men who have condomless sex with female and/or male partners of unknown serostatus, often reside in metropolitan areas with high HIV prevalence and are less likely to test for HIV than other groups with similar HIV risk behaviors $(5,6)$. 
Universal HIV testing, coupled with regular testing among groups that engage in HIV risk-taking behaviors, is a foundational element of HIV control. Since 2006, the Centers for Disease Control and Prevention (CDC) has recommended universal screening for HIV, and that individuals who engage in HIV risk behaviors should test at least annually, with additional screening as warranted based on risk behavior (7-10). Testing is the entry point to the HIV continuum of care that includes diagnosis, linkage and engagement in HIV medical care, and initiation and adherence to HIV antiretroviral therapy (ART) to achieve viral suppression (10). The UNAIDS, WHO, and the US through the National HIV/AIDS Strategy have set goals for 2020 to improve diagnosis rates among people living with HIV (PLWH), initiate therapy, and achieve viral suppression; all include the goal of having $90 \%$ of PLWH aware of their serostatus $(11,12)$.

Increasing the proportion of persons with HIV aware of their serostatus is the goal of the UNAIDS 90-90-90 treatment target in 2020 (13) but subgroup disparities in HIV testing undermine achieving this goal. For populations with HIV risktaking behaviors, regular testing is critical, given that most individuals reduce HIV transmission risk behaviors following an HIV diagnosis, that early ART treatment reduces risk of transmission to sexual and drug using partners by lowering viral load, and at an individual level lowers risk for AIDS-defining illnesses and death (14). Additionally, improved screening and detection of HIV at the community level leads to lowered community viral load and a reduced proportion of persons in a potential partner pool with detectable viral load (15), ultimately reducing societal-level suffering and costs associated with HIV/AIDS (16). Despite policy approaches to expand HIV testing to diverse clinical care settings, to implement "opt out" procedures for integrating HIV testing into other standard screening approaches, and to mount community-level campaigns to increase awareness about the importance of HIV screening, disparities in HIV testing among Black populations, especially Caribbean men, persist (17-19).

In Brooklyn, New York (NY), which has the largest Caribbean community in the US, the highest percentage (33\%) of new HIV diagnoses are among FB Caribbean individuals, 75\% of whom are men (20). New York City (NYC) recently achieved the $90 \%$ HIV testing federal goal (21); however, HIV screening among FB Black men with HIV risk-taking behaviors remains suboptimal. Numerous studies have found that late HIV testing is common among FB individuals from the Caribbean (3, 22, 23). Risk factors that adversely affect HIV testing among Black men with HIV risk behaviors, including FB Black Caribbean men, are complex and comprise individual, interpersonal, and structural-level barriers. For example, gender norms surrounding masculinity may impact sexual stereotypes (and associated behaviors) placed on Black men who have sex with men (MSM), along with HIV/STI testing behavior and communication $(24,25)$. Indeed, culturally oppressive heteronormative gender roles and ideologies perpetuate transmission risk associated with masculinity $(26,27)$. In addition to oppressive gender norms ascribed to Black men surrounding HIV transmission risk, individual barriers to testing include low perceived risk, endorsing HIV conspiracy beliefs, and perceived low access to testing $(26,27)$.

Since the inception of the global HIV/AIDS pandemic, there has been a parallel pandemic of stigma and discrimination fueled by blaming the "dangerous infected other" (28). Dr. Jonathan Mann called this the "third level of the AIDS pandemic" (29, 30) and stated that "discrimination is found not only to be [sic] tragic results of the AIDS pandemic, but to be the root societal cause of vulnerability." HIV stigma, distinct from HIV discrimination, is the ascription of negative attitudes, beliefs and stereotypes about PLWH as undesirable due to fears of contagion, death, or affiliation with "spoiled identity" (31) that diminishes social status, health and wellbeing and produces harmful social consequences $(32,33)$ and health disparities (33). Fears of loss of privacy, social support and being ostracized due to HIV stigma have had a negative impact on preventive behaviors [e.g., condom use or anti-retroviral therapy (ART) adherence] and has hampered the uptake of HIV testing (34, 35). Internalized HIV stigma has been associated with sexual transmission risk behaviors, including condomless sex $(36,37)$ and lower likelihood of regular HIV testing (38, 39). HIV screening among FB Black men is influenced by HIV stigma, primarily as it relates to having prejudiced attitudes toward PLWH that perpetuates fears of the social consequences with an HIV diagnosis (40).

Guided by an understanding of intersectional stigma and an ecological model of social determinants of health, this review explores how FB Black Caribbean individuals who inhabit multiple and intersecting stigmatized identities face additional barriers to HIV testing $(41,42)$. In this review, we also examine gaps in HIV testing initiatives and describe potential novel approaches to lessen barriers and intersectional stigma and develop sustainable HIV testing, treatment, and care programs for this marginalized priority population.

\section{FB PERSONS WITH HIV IN THE US}

FB persons with new HIV diagnoses, compared with newly diagnosed HIV-positive US-born persons, have different group characteristics due to factors related to their immigration pathway, education, health status, local social networks, and the specific risk factors that characterize the global HIV epidemic $(5,23,43,44)$. FB persons with HIV include skilled workers and students pursuing college or graduate training, while other FB persons have become naturalized citizens or immigrate because they have family members that are US citizens or have strong social networks in place in the US (2). The most vulnerable FB individuals with HIV are those that come as undocumented migrants, asylum seekers or refugees who, based on their vulnerable status, have been exposed to political or discriminatory violence due to sexual orientation; some also experience sexual abuse and HIV exposure $(45,46)$. How vulnerable FB immigrants arrive in the US also impacts how they access health information, insurance, and health care, increasing for some the risk of HIV exposure $(47,48)$. 
Until recently, there was little information about FB Black persons because they were often subsumed under the singular racial category of being "Black." Ojikutu, Nnaji et al. argued that "All Black People Are Not Alike" in HIV surveillance data and that to explore the epidemiological diversity and more accurately identify HIV prevalence within Black immigrant subgroups, we must disaggregate racial categories by country of birth (23). Thus, grouping US-born and FB Blacks into a single homogeneous racial category masks important sociocultural, linguistic and historical differences that influence health behaviors but also ignores the important impact that migration can have on FB Black's health-seeking behaviors, including HIV testing (49).

\section{HIV INFECTION AMONG FB CARIBBEAN BLACKS}

HIV disproportionately affects FB Black men in the US who engage in HIV risk behaviors $(2-5,50,51)$. In a modeling analysis, the CDC projected that approximately 4,275 FB persons with HIV could immigrate each year to the US (95\% CI, 9665768 persons), assuming that mostly healthier persons would be able to immigrate and that a more accurate prediction may be the lower end of the confidence interval $(2,52)$. With regard to Caribbean countries of origin, Haiti and Jamaica had the second and eighth highest total number of HIV diagnoses among FB and permanent residents in the US, respectively. California, Florida, NY, and Texas have the highest numbers of FB persons diagnosed with HIV and highest percentages of overall HIV cases in the US (3). In 2016, FB Black individuals from the Caribbean accounted for $22 \%$ of new HIV diagnoses in the US, and $70 \%$ of those new diagnoses were among FB MSM compared to $75 \%$ of USborn men who acquired HIV through MSM contact (2); and $39 \%$ of new infections were attributable to heterosexual behavior compared to $27 \%$ among US-born persons $(2,3)$. One study found that Black West Indian men were less likely than were US-born Black men to report non-regular partners (53). Using data from the NYC HIV surveillance registry and American Community survey, another study determined that $61 \%$ of $\mathrm{FB}$ infections occurred in the US (51); and that the likelihood of the acquisition of HIV in the US was higher for FB males than FB females (68 vs. 50\%), and higher for FB MSM (76\%), thus highlighting the urgency to promote HIV prevention among new immigrant groups (51).

\section{FB BLACK MEN AND MULTI-LEVEL BARRIERS TO HIV TESTING}

Late HIV testing is common among immigrants from the Caribbean $(3,4,6,22,23,43)$. Despite late presentation to HIV care, studies have shown that among FB persons there was no difference in retention in care or virologic suppression compared to US-born persons (54). In the US, factors that account for disparities in HIV screening among Black men with HIV risk behaviors (5, 55-57), including FB Black Caribbean men, are increasingly known $(6,22)$. Disparities in HIV testing among both US-born and FB Black men with HIV risk behaviors are associated with poor socioeconomic status and greater income inequality (58), poor access to health services (59), decreased access to HIV screening and treatment services (60), delayed health screening (61), and lower engagement with existing social services and related prevention services (62-64). However, numerous studies have noted that differences in HIV testing patterns between FB Black and US-born Blacks are also influenced by nativity $(5,23,43)$. Lower levels of HIV testing among FB Black men with HIV risk behaviors, as compared to their US-born male counterparts, is also influenced by differential access to HIV testing and knowledge of how to access testing, lower health insurance coverage (65), and lower familiarity with the US health care system (6). In a recent assessment of 875 Black men with HIV risk behaviors in Brooklyn who reported multiple female partners and condomless sex in the past 6 months, 76\% were FB Blacks and only 51\% reported HIV testing in the past year (56). Reasons for low HIV testing rates among FB men have included privacy concerns and misconceptions about HIV transmission (66). Another study found that barriers to HIV testing for recent vs. long term immigrants were also due to health access, fatalism and anticipated HIV stigma (6). Among FB Black men with HIV risk behaviors, the benefit of testing more frequently than annually is unknown (67) and warrants investigation, especially since Caribbean men are likely to acquire $\mathrm{HIV}$ in the US. Multi-level factors related to immigration status may further undermine FB Black men's access to HIV screening in the US (Table 1).

\section{Structural and Policy-Level Factors}

A policy-level factor that undermines access to HIV testing for FB Black persons was the removal of HIV testing at US points of entry, which was an unintended consequence of the repeal of the 22-year HIV immigration ban in $2010(69,70)$. The HIV immigration ban, which was first instituted in 1987, prevented non-US citizens with known HIV diagnoses from entering the country (71). The ban permitted the exclusion, removal or deportation of PLWH from the United States. Although the repeal of the HIV immigration ban was considered a watershed moment in eliminating HIV stigma and exceptionalism for PLWH in the US, that repeal of the ban may have inadvertently created more missed opportunities for early diagnosis (69). The repeal of the ban eliminated mandatory HIV testing as part of the physical examination and consequently removed access to free screening at all United States' points of entry. Following the repeal of the ban, the rate of HIV infection among FB individuals rose, especially among persons from the Caribbean. One study found that between 2011 and 2015, the highest rates of HIV infection (8.4\%) were among Caribbean men (18).

Two other policy-level barriers to HIV testing for immigrants are restrictions to access Medicaid, and anti-immigrant, antiBlack racism and HIV criminalization laws (72). In the US, legal immigrants are restricted for 5 years after their arrival from accessing federal health benefits, such as Medicaid (73). For the FB Black man unaware of his serostatus, a 5-year delay in access to Medicaid and HIV screening increases the likelihood of HIV transmission. For a FB Black man living with HIV, 5 years without access to antiretroviral therapy could be devastating 
TABLE 1 | Multi-level factors influencing HIV screening among FB Black men with HIV risk behaviors.

\begin{tabular}{|c|c|c|}
\hline Individual & Community & Policy \\
\hline $\begin{array}{l}\text { - Fear of social consequences of an HIV } \\
\text { diagnosis/loss of confidentiality (e.g., discrimination) } \\
\text { - Lack of familiarity with US health care system } \\
\text { - Distrust of the medical care system and government } \\
\text { - Low perception of personal HIV risk and inadequate } \\
\text { knowledge about HIV transmission and testing }\end{array}$ & $\begin{array}{l}\text { - High HIV-associated stigma } \\
\text { - Prejudice/stereotypes toward PLWH and groups } \\
\text { with HIV risk behaviors } \\
\text { - Normative distrust in the medical care system } \\
\text { - Available testing venues are not } \\
\text { advertised/communicated, especially in Creole or } \\
\text { languages other than Spanish } \\
\text { - Low normative expectations of HIV } \\
\text { screening/Gender normative expectations regarding } \\
\text { - } \text { clinics are female spaces } \\
\text { - Real men don't go to doctors }\end{array}$ & $\begin{array}{l}\text { - No HIV testing at US points of entry } \\
\text { - No access to Medicaid } \\
\text { for } 5 \text { years after immigration } \\
\text { - Lengthy immigration process } \\
\text { - HIV criminalization laws and fears of deportation } \\
\text { - Low access to free and confidential/anonymous } \\
\text { testing in venues where FB Black men are likely to } \\
\text { interface } \\
\text { - Few health promotion opportunities emphasize the } \\
\text { importance of HIV screening }\end{array}$ \\
\hline
\end{tabular}

\begin{tabular}{|c|c|c|c|}
\hline $\begin{array}{l}\text { Health outcomes } \\
\text { associated with } \\
\text { improved screening }\end{array}$ & $\begin{array}{l}\text { Greater likelihood of viral } \\
\text { suppression; less risk behavior; } \\
\text { improved quality and length of life }\end{array}$ & $\begin{array}{l}\text { Decreased risk of HIV transmission } \\
\text { to partners }\end{array}$ & $\begin{array}{l}\text { Lower community viral } \\
\text { load/proportion with } \\
\text { suppressed viral load }\end{array}$ \\
\hline
\end{tabular}

*Adapted from the NIMHD Minority Health and Health Disparities Research Framework (68).

to his health. The lengthy process for establishing residency or citizenship status to legally work or access health care can further delay access to health care and HIV testing (73). Breanne Palmer (74) argues that anti-immigrant and anti-Black racism in the US legal system has resulted in a disproportionate mass criminalization and deportation of Black immigrants from the Caribbean, compared to immigrants of other races (75). Using public records on US Deportation proceedings in immigration courts, Palmer found that $20.3 \%$ of FB individuals deported for committing a crime were Black (74).

Another legal scholar, found that under the illegal NYC "stop and frisk" policy those racially profiled were mostly Black and Latino men, and $98 \%$ were deported and $75 \%$ of those deportees were male (76). Tanya Golash-Boza (76), whose research focuses on Caribbean populations, found that $10 \%$ of deportees in the US were Jamaican, who make up only $2 \%$ of legal permanent residents. Police cooperation with Immigration and Customs Enforcement (ICE) in non-sanctuary cities under President Trump's administration has fostered ambivalence and mistrust of the police in Black immigrant communities (77-80). There is evidence that some migrants underutilized HIV testing resources because of misconceptions about immigration laws and that seeking care or a positive test could result in deportation (81, 82). HIV criminalization laws that broadly penalize alleged or perceived non-disclosure of, and exposure to, HIV and nonintentional HIV transmission with incarceration can be an even more detrimental policy-level barrier to HIV screening (83, 84) among FB Blacks because being convicted of a crime can be grounds for deportation. And those deported may likely have even fewer HIV prevention resources available in their home countries.

\section{Societal-Level Factors}

Societal barriers to HIV testing that are specific to FB Black men include anti-immigrant bias, oppressive heteronormative gender roles, and masculine ideologies. Studies have found that xenophobia undermines mental health; however, little is known about xenophobia as a social determinant of health. In an integrative review of the literature, Suleman et al. (85) found that, globally, xenophobia is a "political threat" that can have a deleterious impact on the health and wellbeing of immigrant communities. A well-documented example of stigmatizing or ostracizing a population is the US medical, political, and social response to Haitian-Americans and Haitian immigrants during the 1980s and 1990s when HIV/AIDS was more of a death sentence (86-89). Anti-immigrant rhetoric in the US in the past and present strives to stigmatize and alienate people from other countries. The anti-immigrant racism that resurfaced prior to the 2016 presidential election and became manifest in new discriminatory policies are thought to limit access to health resources and increase racial and ethnic health disparities among immigrant groups and undocumented persons (90). Morey (91) argues that "immigration policy is also "health policy"' and:

\footnotetext{
"When immigration policy responds to the worst sentiments of antiimmigrant bias with punitive action, disparity-inducing health consequences follow. When this happens, the vision of Healthy People 2020 of " a society in which all people live long, healthy lives" is compromised. We must recognize how the xenophobic and racist underpinnings of the current anti-immigrant environment contribute to widening health disparities (91)."
}

Oppressive, heteronormative gender roles and masculine ideologies are key structural barriers to HIV testing among FB Black men (92). Indeed, oppressive beliefs about masculinity, heteronormativity, and heterosexism have been found to be barriers to HIV testing, not only for gay and bisexual men, but also for heterosexual men $(39,93)$. Gender norms within the Black Diaspora are strikingly similar and create both barriers and facilitators to HIV testing that could include: a man's fear of losing his marriage and ability to provide for his family with a positive HIV test result; fear of being blamed for the spread of HIV; internalized feelings of shame; the perception that clinics are a female space and that "real men" don't go to doctors because 
it highlights their weakness instead of stoicism and self-reliance; threats to masculinity due to fears that a positive HIV screen might curtail their sexual prowess; and/or being exposed for infidelities, or philandering behavior (94). Mburu et al. argued that HIV stigma "threatened masculine notions of reputation and respectability, independence and emotional control, while it amplified men's risk-taking" and influenced men's participation in HIV services (95). In many African communities, to reveal that one is sick is a stigmatized identity, which extends beyond the individual to the family (96). The stigmatizing sick self is perceived as more severe for men due to the association of sickness as the antithesis of masculine strength (97). Mburu et al. (95) also found that seeking HIV prevention services, or any type of health care, meant that they publicly accepted the stigmatized sick role. Community-level interventions that fostered contact or visibility with the disaffected groups and targeted negative stereotypes have proved effective in reducing HIV stigma and homophobia (98).

\section{Community-Level Factors}

Community-level factors that impact HIV testing for both FB and US-born Black men include HIV-associated stigma (99-103), low normative expectations regarding HIV testing (53, 104), and endorsement of HIV conspiracy beliefs and medical and/or government mistrust $(66,105)$ that are rooted in historical societal abuses, which create distrust in HIV screening services and higher refusal rates when routine testing is offered $(106,107)$. However, distinct to FB Black men, there is the challenge of assimilating to US culture and society that may similarly create barriers to access to health prevention screening (108-110), including HIV testing. The process of migrating to another country and cultural system is stressful and often impacts community health outcomes (111-113), including HIV risk behaviors and low HIV screening (114). Losing access to protective social networks are thought to be driving factors of increased vulnerability to HIV infection (115-117). Migrants have fewer economic, cultural and psychosocial resources and often experience difficulty coping with stressful changes of living in another country, which may increase sexual risk behaviors (6). One study found that FB and US-born differences in HIV testseeking and HIV prevention services are likely due to FB status and the loss of protective, pre-migration sexual networks (49). A study in Canada among Muslim immigrants found that longer time spent in a new country increased knowledge but decreased likelihood of HIV testing (118).

Acculturation has been found to be a key driver in HIV-related sexual behaviors and among immigrants (50, 114, 119-122). A systematic review and subset meta-analysis (119) found that immigrants with high levels of acculturation was associated with condomless sex, sexually transmitted infections (STIs), multiple partners and early sexual debut. They also found that gender moderated the relationship between acculturation, condomless sex, and STIs, and that the relationship between acculturation and condomless sex also varied across different ethnic groups (119). Despite these findings, a key limitation of this study is that most studies examined focused on Hispanics and Latinx samples or female immigrants. Saint-Jean et al. (50) found that the challenges of acculturation in the US and poverty have placed Caribbean-born Black immigrants at higher risk of substance abuse and HIV infection. Despite these challenges, other research has also shown that social integration and political empowerment for some Caribbean communities, including the Haitian and Jamaican communities in NY, has fostered wellbeing $(123,124)$.

\section{Individual-Level Factors}

Individual-level factors known to lower HIV screening among FB Black men include: lower knowledge of HIV transmission, lower perception of personal or partner HIV risk, reservations or fears about breaches of confidentiality, and potential societal consequences, lack of knowledge about where and how to access testing, speaking a language other than English, low income, no regular provider due to a lack of familiarity with US healthcare system, and recent immigration $(6,125,126)$. English-language proficiency is also a known barrier to accessing HIV testing and health care in general (127). Francophone and Haitian immigrants in Brooklyn face greater challenges to accessing health care because of less English fluency and undocumented status (128). Language and cultural barriers can make it harder for many FB individuals to access information about HIV prevention and where to access HIV screening (129). Second, FB Black men are less likely to have a usual source of care or to utilize general preventive care services $(130,131)$, and are therefore less likely to have routine HIV screening offered, with the exception of men who are currently incarcerated and receive mandatory HIV screening $(132,133)$. A lack of familiarity with how to navigate the US health care system and system of Medicaid entitlements is another key barrier to accessing HIV prevention and screening services (134).

\section{INTERSECTIONAL STIGMA}

Building on the pioneering theory of intersectionalities (135, 136), the framework of intersectional stigma links exposure to oppression with experiences of stigma (137). Individuals with anticipated, perceived, enacted, or internalized HIV stigma often inhabit various marginalized social identities; and have exposure to multiple forms of oppression, known as intersectional stigma. Forms of privilege and oppression intersect with HIV (138, 139), and other stigmatized social identities, such as race and ethnicity, nationality, gender identity, sexual orientation, sexual practices, mental health, and addictions that may increase the cumulative burden of psychological distress (140), contribute to poor clinical outcomes (141) and create disparities in HIV screening $(141,142)$, especially among Black men $(143,144)$. However, stigmatized identities have often been analyzed in isolation, ignoring the convergence of intersecting forms of stigma or multiple stigmatized identities that is the reality for many individuals and groups (145). FB Black gay and bisexual men at-risk of acquiring HIV who have low levels of HIV screening $(141,142)$ may experience layered or intersectional oppression due to racism, anti-immigrant bias, homophobia, and HIV discrimination at work, home, in their communities, as well as while accessing healthcare and HIV screening services. 


\section{Racism: Being a Black, Cis-gender Man}

FB Black men experience perceived or anticipated racial or ethnic discrimination in health care settings $(61,146)$. The influence of perceived racism on HIV testing is not well understood and studies have found mixed results. For example, some studies have found that perceived everyday racism or beliefs in racialized conspiracy theories may improve the likelihood of HIV testing, while other studies have found that perceived healthcare-specific racial discrimination or government/medical mistrust is not a major barrier contributing to the sub-optimal frequency of HIV testing $(105,106,147,148)$. One study found that perceived racism was not inherently detrimental and that it may increase the likelihood of HIV testing and early detection of HIV infection. A clinic-based study in North Carolina found that $90 \%$ of the sample had experienced perceived racism and that it was associated with higher odds of HIV testing (147). Alternatively, perceived racism and medical mistrust were found to undermine PrEP awareness and uptake in Black compared to White gay and bisexual men (149). Racial discrimination has also been found to predict lower adherence to HIV treatment (150). One study found that conspiracy beliefs related to pre-exposure prophylaxis (PrEP) were reported more frequently among Black men and transgender women who have sex with men compared to their White counterparts, and that there is an urgent need to address racial medical mistrust so that individuals at risk will understand the potential benefits of PrEP, a highly effective biomedical strategy for HIV prevention (151).

\section{Racism and Xenophobia: Being a Black Caribbean Man}

Anti-immigrant rhetoric before and after the 2016 presidential campaign fueled xenophobic fears that worsened racial and ethnic disparities, especially among Black undocumented immigrants (91). The anti-immigrant campaign slogan, "Build the wall" supported enthusiasm for the implementation of stringent immigration policies along the US-Mexico border and the Executive Order 13769, entitled Protecting the Nation from Foreign Terrorist Entry into the United States, which was also known as the Muslim ban $(152,153)$. Research suggests that community-level prejudice and xenophobia also increased mortality among immigrant groups (154). Most studies have focused on hate crimes (155-158), especially among transgender and gender-nonconforming individuals (159-161), or police violence and Black Lives Matter before and after the 2016 election (162-165). Seminal studies are now reporting that anti-immigrant policies and sociopolitical stressors are impacting maternal health. Two studies found an association between preterm births among US Latina women and the 2016 presidential election $(90,166,167)$.

The global HIV/AIDS pandemic prompted a dubious epidemic of discrimination and racial prejudice. Nations experiencing the pandemic have blamed the "other"-those foreigners or marginalized groups within their society-in order to relocate the source of the deadly contagion safely outside the boundaries of the national identity. In 1988, Dr. Jonathan Mann (30) referred to this process of "shifting the blame" onto the "outsider" as the Third Level of the AIDS epidemic. The first level was (and continues to be) the "silent" and undetectable suffusion of HIV infection; followed by the inevitable second tier, which is the visible physical manifestation of the disease syndrome. The third level of the AIDS epidemic is defined as the concurrent epidemic of "blame" and "accusation" (87), in which the "social, cultural, economic, and political reactions to AIDS... [is]... as central to the global AIDS challenge as the disease itself" (30). These social beliefs and fears of contagion, and its causal transmission have resulted in the social control, surveillance, and stigmatization of those infected and afflicted, compromising their right to public health and civil liberties. Today, there is a dearth of research on the intersection of xenophobia, racism and HIV stigma or HIV testing; however, we could speculate that there continues to be an epidemic of blaming the foreign other. More research is needed to explore the impact of anti-immigrant bias on perceived HIV stigma and low HIV testing.

\section{Homophobia and Racism: Being a Black, Gay, or Bisexual Man}

Since the beginning of the HIV epidemic in the US, homophobia has been central to the parallel pandemics of stigma and discrimination (168). However, understandings and experiences of homophobia vary across cultures. Studies have also found a synergism with racism and minority sexual orientation status. Layered or intersecting stigmas due to racism, homophobia, and HIV have made those individuals who are "triply cursed" reluctant to pursue HIV testing $(169,170)$. In several studies, researchers found that implicit racist and homophobic biases among health care providers may limit access to PrEP among those patients most in need. A study among medical students found that a prevention paradox in their lack of willingness to prescribe PrEP was inconsistent with patient risk and may have been impacted by implicit racial bias (171). Using data from the Urban Men's Health Study, another study found that the combination that racism and minority sexual orientation status has impacts on Black MSM's encountered everyday racism, and thus Black MSM have a less positive experience with the gay community than their White counterparts (172).

A similar study found that Black MSM encounter racism and a less positive experience within the gay community than their White counterparts, suggesting that racism may shape the extent to which gay community affiliation serves as a protective factor against HIV for Black MSM (173). In a qualitative study in Boston (MA) and Jackson (MI), Cahill et al. (149) found evidence that providers and health departments are not adequately addressing medical mistrust among Black gay and bisexual men and other MSM. Black HIV-positive MSM who experienced greater racial discrimination were found less likely to achieve viral suppression compared to Latino HIV-positive MSM (174). Identifying particular sources of perceived racism in health care settings or circulating conspiracy discourses in the Caribbean immigrant community would help to tailor HIV testing strategies for FB Black men. 


\section{APPROACHES TO REDUCE STIGMA OF HIV TESTING}

UNAIDS recommends that every nation's HIV response should include specifically targeted programs to reduce stigma (175). A review of stigma interventions (176) shows that stigma can manifest on multiple levels, including the intra-personal (e.g., individual-level interventions that aim to reduce the impact of stigma by changing behavior, attitudes, or psychosocial outcomes), interpersonal (e.g., small group-level interventions among individuals who may or may not share the same stigma status, such as HIV serostatus discordant couples), and structural-level (e.g., mass media, change in government or institutional policy). Stigma-focused interventions have generally been delivered in-person; while demonstrating efficacy, these interventions have been implemented on a relatively small scale (177). HIV prevention interventions that include Black MSM have included stigma as an intervention topic (178-180) and a growing number of eHealth interventions have been developed for Black MSM $(178,181,182)$ but few interventions have addressed intersectional stigma $(169,183)$. To date, there are few effective interventions for cis-gender, gay or bisexual FB Black Caribbean immigrant men to promote HIV testing (18). We conducted a review of evidence-based interventions and identified six interventions, ranging from individual to community-level, which target different determinants of HIV prevention and testing, some of which also address stigma.

\section{Self-Testing}

To date, few effective interventions exist for FB Black-Caribbean immigrants to promote HIV testing (18). HIV self-testing via the OraQuick In Home HIV Test does not require interfacing with a clinical setting and has been found to increase self-testing in cohort studies and clinical trials $(184,185)$. Self-testing for HIV is hypothesized to also reduce the impact of HIV stigma and possibly HIV conspiracy beliefs on testing behaviors $(186,187)$. However, the prohibitive cost of OraQuick limits its sustainable use in resource-poor settings where many live below the federal poverty line. In addition, the high false-negative rate and inability to detect acute HIV infection are limitations of OraQuick (188). An alternative stigma reduction strategy for HIV self-testing is via Dried Blood Spot (DBS) self-collection kits (189). DBS home collection is currently used for research and clinical purposes to improve access to HIV testing in low-resource settings where access to healthcare and advanced lab techniques are limited (190, 191). DBS self-collection is becoming more common in the US and has been used successfully for self-collecting blood samples for laboratory-quantified viral load among MSM (192). DBS selfcollection may become a lower-cost option for collecting blood and mailing the specimen for laboratory-based HIV testing.

\section{Health Education in the Clinic}

Health education interventions can inform both stigmatized and non-stigmatized groups about health issues and reduce perceived stigma by normalizing educational information as part of a general health care visit. A study by Armstrong et al. (193) found that low income Black and Latino men who received the educational intervention reported lower sexual risk and greater sexual health knowledge and health behaviors three months after the intervention. A part of the aforementioned educational intervention is to "teach back," where the provider teaches the patient health information and then asks the patient to explain what they learned. Healthcare practitioners routinely include "teachable moments" during routine visits to educate patients.

Aung et al. argue that provider-initiated testing and counseling may be the most promising because they foster trust in both the provider and in health systems (82).

\section{Individual Counseling}

Counseling and referral for social support services can be used to provide basic prevention information to screen for unmet needs related to housing, mental health services, and substance use care, and can facilitate navigation to these services $(194,195)$. These approaches address the HIV screening determinants of HIV transmission and prevention knowledge, address gaps in access to HIV prevention information in this group, and can address gaps in care for unmet service needs. Contact with PLWH is another established and evidence-based strategy to reduce HIV stigma because it can dismantle harmful stereotypes and generalizations that perpetuate fear and misunderstanding (42).

\section{Active Recall}

Brief screening reminders ("active recall") can promote regular HIV testing (196). In a randomized controlled trial of MSM receiving STI services in Australia, brief automated reminders to engage in testing increased HIV/STI screening to $64 \%$ as compared to $30 \%$ in a comparison group. A recent review of interventions using this approach revealed no methodologically rigorous evaluations among men with HIV risk behaviors (196). Thus, there is a need to conduct HIV prevention research with FB Black men, and other at-risk populations, to determine the feasibility of automated reminders for health screening. If feasible, this methodology would be cost-efficient (e.g., it is automated and would not require much human effort; the cost per text is low or included in most phone data plans), highly scalable (e.g., most individuals have a mobile phone), and sustainable.

\section{Male Social Spaces}

Barbershops are a natural site for the conduct of health programs on stigmatized issues, including HIV testing. Most FB Black men with HIV risk-taking behaviors are likely to visit a barbershop on a regular basis. In addition, barbershops are typically located in the customer's own neighborhood, allowing public health efforts to focus on prioritization of high-risk geographic areas. Barbershops are trusted community venues for men, and since Black men are less likely than other subgroups to be exposed to more traditional sources of HIV information, such as clinical settings and faith-based organizations $(197,198)$, they may be more likely to interface with a barbershop than a clinical care setting. Studies have demonstrated the feasibility of partnering with barbershops for HIV prevention efforts, as described in a recent review (198). A recent community-based study in NYC demonstrated success in developing barbershop alliances 
for recruiting Black men (including 35\% FB Black men) for HIV testing programs (199). Thus, partnering with barbershops may be a viable community level approach to increase HIV testing uptake.

\section{Access to Healthcare Services}

Changes in healthcare policy can serve as a structural-level intervention by increasing access to care on a population level. Recent changes in legislation have increased access to healthcare, including the Affordable Care Act (2010), to reduce the number of uninsured individuals. In 2015, the Centers for Medicare \& Medicaid Services (CMS) expanded HIV testing coverage to individuals between the ages of 15 and 65 years (200); however, this does not include undocumented immigrants. The Ending the Epidemic (ETE) federal initiative aims to reach groups living with, or at-risk for, HIV with testing and treatment initiatives (201). A recent report by AIDS United (202) provided a framework through which the ETE could effectively reach populations at highest risk of HIV infection, including documented and undocumented immigrants; this included recommended policy changes to include undocumented immigrants in federal HIV testing programs, such as CMS. It is important to note that some changes in healthcare policy have been the result of lobbying by individuals, groups, or corporations, which shows that those who lobby for health care rights can be a catalyst for change in access to services, including HIV testing (203).

\section{Community-Level Campaigns}

Mass media campaigns serve to educate and expose populations to conditions or topics that may be stigmatizing. However, some community-wide media health education campaigns have inadvertently been stigmatizing. A review of US STI prevention and testing mass media campaigns published between 2000 and 2014 cited stigma as the first issue that can impact STI testing and treatment (204). The review found that the campaigns reached $66 \%$ of their target populations, on average, and were feasible for reaching at-risk or high-risk populations who may not be reached via the healthcare system or similar services. The authors reported common elements of effective mass media campaigns: obtaining feedback from the target audience to understand the needs of the population and appropriate health messaging; having a theoretically based design; training media staff who run the campaign and interact with the population; reaching the target population with culturally informed messaging through multiple venues such as online, apps, magazine ads, and public transportation billboards; establishing or using existing community partnerships that will provide the services (HIV/STI testing, counseling, etc.) and funds to offer "swag" (e.g., branded condoms, lip balm, t-shirts) in order to legitimize and promote the campaign brand; continual process evaluation to adapt and improve the campaign in real-time; conducting an outcome evaluation to measure the public health impact (e.g., HIV testing rates at specified partner locations before, during, and after the campaign); and continued financial support (via grants or fundraising) to maintain the campaign and its impact. A notable finding from this review was that many of the campaigns did not have rigorous evaluation designs (i.e., no control condition), which is critical to measuring the relative success of a public health campaign.

HIV prevention interventions that include Black MSM have included stigma as an intervention topic (178-180) and a growing number of eHealth interventions have been developed for Black MSM $(178,181,182)$, but few interventions have addressed intersectional stigma $(169,183)$. Stigma-focused interventions have generally been delivered in-person and have been implemented on a relatively small scale (177). In order to address various forms of stigma (e.g., homophobia and racism), on a structural level, stigma-focused interventions must reach much larger populations, as well as collaborate with community coalitions including churches $(205,206)$. As an example, Frye et al. (207) conducted a rigorous randomized cluster-design trial of community-level intervention on HIV stigma, homophobia, and HIV testing in Black-Caribbean neighborhoods in NYC and found a 350\% increase in HIV testing in that neighborhood compared to a control community. Another example of addressing HIV testing on a structural level is by reaching at-risk and high-risk individuals online or via apps. In 2018, Grindr.com implemented an HIV testing reminder system on its site (208) and included HIV status for members to self-identify (e.g., HIV negative, HIV positive, undetectable). Grindr has become as nearly ubiquitous in the MSM community as Facebook is in the general population and could function as an HIV prevention platform, thus reducing stigma associated with testing and with sexual orientation. Similarly, Black MSM and FB Black men may be encouraged to test through mobile apps developed for supportive healthcare interactions and facilitation $(209,210)$.

\section{Role of Faith-Based Community}

Sanders and Ellen (205) suggest that addressing structurallevel issues in communities may reduce racism and poverty more quickly and efficiently. For example, including federal HIV prevention funding for African American community coalitions, including churches, is one way to address racial/ethnic disparities in access to HIV testing and care (205). A review of HIV testing initiatives in Black churches found that, although testing is becoming more available at churches, there is a great need for collaboration between faith-based organizations and public health entities to increase HIV testing and linkage to care $(206,211)$. Another example to address racial/ethnic HIV testing disparities by involving Black churches is spurring Youth movements through social media; with support from church leadership, Youth movements could help to normalize HIV testing in churches, and consequently reduce HIV testing stigma.

\section{Gender-Transformative Interventions}

Gender-transformative interventions (GTI) "seek to reshape gender relations to become more gender equitable through approaches that 'free both men and women from the impact of destructive gender and sexual norms"' $(92,212)$. Gender within the GTIs is considered as a key social determinant of men's health and has largely focused on understanding masculinity as a set of normative beliefs that is fluid and modifiable. A systematic 
review of gender-transformative health interventions targeting HIV-related outcomes found 9 out of 11 interventions resulted in statistically significant reductions in sexual risk behaviors and 11 out of 12 violence reduction interventions found statistically significant changes toward gender equality (213). Participants in the pioneering One Man Can Program in South Africa (92) reported greater willingness to pursue HIV testing and fewer concerns about the stigma associated with HIV testing.

\section{CONCLUSION}

In the US, foreign-born (FB) Black men from the Caribbean with HIV risk-taking behaviors are disproportionately affected by HIV. This disparity, in part, is driven by disparities in HIV screening. Known barriers to HIV testing, such as perceived, anticipated, internalized HIV stigma, low perceived risk, endorsing HIV conspiracy beliefs, and perceived low access to testing are common among FB Blacks. Similarly, established social determinants of sickness and disease that stem from systematic forms of privilege and oppression (e.g., such as poverty, gender inequality, unemployment and limited access to education, quality health care and health promotion information) also undermine the ability of FB Blacks to engage in early testing, care and treatment $(3,4)$. However, more attention is needed to address the combined impact of layered social stigmas on disparities in HIV screening. And less is known

\section{REFERENCES}

1. US Census Bureau. The Foreign-Born Population in the United States. American Community Survey 2010. (2012). Available online at: https:// www.census.gov/content/dam/Census/library/publications/2012/ acs/acs19.pdf. (accessed October 24, 2019).

2. Prosser AT, Tang T, Hall HI. HIV in persons born outside the United States, 2007-2010. JAMA. (2012) 308:601-7. doi: 10.1001/jama.2012.9046

3. Demeke HB, Johnson AS, Wu B, Nwangwu-Ike N, King H, Dean HD. Differences between US-Born and Non-US-Born black adults reported with diagnosed HIV infection: United States, 2008-2014. J Immig Minor Health. (2019) 21:30-38. doi: 10.1007/s10903-018-0699-4

4. Demeke H, Johnson A, Zhu H, Gant Z, Duffus W, Dean H. HIV infectionrelated care outcomes among US-born and non-US-born blacks with diagnosed HIV in 40 US areas: the National HIV Surveillance System, 2016. Int J Environ Res Public Health. (2018) 15:2404. doi: 10.3390/ijerph151 12404

5. Ojikutu B, Nnaji C, Sithole J, Schneider KL, Higgins-Biddle M, Cranston $\mathrm{K}$, et al. All black people are not alike: differences in HIV testing patterns, knowledge, and experience of stigma between US-born and non-USborn blacks in Massachusetts. AIDS Patient Care STDs. (2013) 27:45-54. doi: 10.1089/apc.2012.0312

6. Ojikutu B, Nnaji C, Sithole-Berk J, Bogart LM, Gona P. Barriers to HIV testing in black immigrants to the US. J Health Care Poor Underser. (2014) 25:1052. doi: 10.1353/hpu.2014.0141

7. Branson BM, Handsfield HH, Lampe MA, Janssen RS, Taylor AW, Lyss SB, et al. Revised recommendations for HIV testing of adults, adolescents, and pregnant women in health-care settings. MMWR Recomm Rep. (2006) 55:117; quiz CE1-4. Available online at: https://www.cdc.gov/nchs/products/ databriefs/db202.htm. (accessed October 9, 2019).

8. Branson BM, Owen SM, Wesolowski LG, Bennett B, Werner BG, Wroblewski KE, et al. Laboratory testing for the diagnosis of HIV infection: updated recommendations (2014). doi: 10.15620/cdc.23447 about the links between heteronormative masculine gender roles and ideologies, intersectional stigma and HIV risk. Stigmatized identities have often been analyzed in isolation, but the reality is that intersecting forms of stigma or stigmatized identities seldom operate alone. Caribbean-born, Black gay, bisexual, or heterosexual men living with or at-risk of HIV experience exponential internalized stigma and oppression due to racism, anti-immigrant bias, and homophobia, as well as discrimination at work and in their communities while accessing healthcare and HIV screening services. More culturally responsive research is needed to explore the impact of intersecting stigmas on HIV testing and address the critical gap of HIV risk and poor clinical outcomes across the HIV continuum of care in this priority population.

\section{AUTHOR CONTRIBUTIONS}

TT developed the topic area and wrote sections of the manuscript. SH wrote sections of the manuscript and provided feedback. JD reviewed and provided feedback on several versions of the manuscript.

\section{ACKNOWLEDGMENTS}

The authors would like to thank Dr. Tracey Wilson for her review and feedback on a draft of the manuscript.

9. Copen CE, Chandra A, Febo-Vazquez I. HIV Testing in the Past Year Among the U.S. Household Population Aged 15-44: 2011-2013. NCHS data brief, no 202. Hyattsville, MD: National Center for Health Statistics (2015). Retrieved from: https://www.cdc.gov/nchs/products/databriefs/db202.htm (accessed October 9, 2019).

10. Gonsalves GS, Paltiel AD, Cleary PD, Gill MJ, Kitahata MM, Rebeiro PF, et al. A flow-based model of the HIV care continuum in the United States. J Acquir Immune Defic Syndr. (2017) 75:548-53. doi: 10.1097/QAI.0000000000001429

11. Joint United Nations Programme on HIV/AIDS, and Joint United Nations Programme on HIV/Aids. 90-90-90: An Ambitious Treatment Target to Help end the AIDS Epidemic. Geneva: Unaids (2014).

12. The National HIV/AIDS Strategy. Updated to 2020. Washington, DC: The White House (2010)

13. Joint United Nations Programme on HIV/AIDS. 90-90-90: An Ambitious Treatment Target to Help end the AIDS Epidemic. Geneva: UNAIDS (2014).

14. Cohen MS, Chen YQ, McCauley M, Gamble T, Hosseinipour MC, Kumarasamy N, et al. Antiretroviral therapy for the prevention of HIV-1 transmission. N Eng J Med. (2016) 375:830-9. doi: 10.1056/NEJMoa1600693

15. Miller WC, Powers KA, Smith MK, Cohen MS. Community viral load as a measure for assessment of HIV treatment as prevention. Lancet Infect Dis. (2013) 13:459-64. doi: 10.1016/S1473-3099(12)70314-6

16. Long EF, Brandeau ML, Owens DK. The cost-effectiveness and population outcomes of expanded HIV screening and antiretroviral treatment in the United States. Ann Inter Med. (2010) 153:778-89. doi: 10.7326/0003-4819-153-12-201012210-00004

17. Kwakwa H, Wahome R, Bessias S. HIV disparities in a US and foreignbornn cohort in urban United States. J AIDS Clin Res. (2015) 6:2. doi: 10.4172/2155-6113.1000515

18. Kwakwa HA, Wahome R, Goines DS, Jabateh V, Green A, Bessias S, et al. Engaging African and Caribbean immigrants in HIV testing and care in a large US city: lessons learned from the African diaspora health initiative. $J$ Immigr Minor Health. (2017) 19:818-24. doi: 10.1007/s10903-016-0431-1 
19. Nunn A, Yolken A, Cutler B, Trooskin S, Wilson P, Little S, et al. Geography should not be destiny: focusing HIV/AIDS implementation research and programs on microepidemics in US neighborhoods. Am J Public Health. (2014) 104:775-80. doi: 10.2105/AJPH.2013.301864

20. Hygiene, N. Y. C. D.,o.H.a.M. HIV/AIDS Among People Born Outside of the US and in New York, City, 2017. H.E.a. FS Program, Editor (2018).

21. Xia Q, Lazar R, Bernard MA, McNamee P, Daskalakis DC, Torian LV, et al. New York City achieves the UNAIDS 90-90-90 targets for HIV-infected whites but not Latinos/Hispanics and blacks. JAIDS J Acquir Immune Def Syndrom. (2016) 73:e59-62. doi: 10.1097/QAI.0000000000001132

22. Valverde E, DiNenno E, Oraka E, Bautista G, Chavez P. HIV testing among foreign-born men and women in the united states: results from a nationally representative cross-sectional survey. J Immigr Minor Health. (2018) 20:1118-27. doi: 10.1007/s10903-017-0655-8

23. Koku EF, Rajab-Gyagenda WM, Korto MD, Morrison SD, Beyene Y, Mbajah J, et al. HIV/AIDS among African immigrants in the US: the need for disaggregating HIV surveillance data by country of birth. J Health Care Poor Underser. (2016) 27:1316-29. doi: 10.1353/hpu.2016.0128

24. Fleming PJ, Lee JG, Dworkin SL. "Real Men Don't": constructions of masculinity and inadvertent harm in public health interventions. Am J Public Health. (2014) 104:1029-35. doi: 10.2105/AJPH.2013.301820

25. Calabrese SK, Earnshaw VA, Magnus M, Hansen NB, Krakower DS, Underhill K, et al. Sexual stereotypes ascribed to Black men who have sex with men: an intersectional analysis. Arch Sex Behav. (2018) 47:143-56. doi: 10.1007/s10508-016-0911-3

26. Bowleg L, Teti M, Massie JS, Patel A, Malebranche DJ, Tschann JM. 'What does it take to be a man? What is a real man?': ideologies of masculinity and HIV sexual risk among Black heterosexual men. Cult Health Sex. (2011) 13:545-59. doi: 10.1080/13691058.2011.556201

27. Bowleg L, Heckert AL, Brown TL, Massie JS. Responsible men, blameworthy women: Black heterosexual men's discursive constructions of safer sex and masculinity. Health Psychol. (2015) 34:314. doi: 10.1037/hea0000216

28. Taylor TN. (1998). Blaming the infected african other: an epidemic of discrimination. In: Ali-Dinar AB, Editor. Sixth Annual African Studies Consortium Workshop. Philadelphia, PA: University of Pennsylvania African Studies Center University of Pennsylvania. Available online at: http://www. africa.upenn.edu/Workshop/tonya98.html

29. Mann JM, Chin J, Piot P, Quinn T. The international epidemiology of AIDS. Sci Am. (1988) 259:82-9. doi: 10.1038/scientificamerican1088-82

30. Mann JM. Statement at an informal briefing on AIDS to the 42 nd session of the United Nations General Assembly. J Roy Statist Soc Ser A. (1988) 151:131-6. doi: 10.2307/2982189

31. Goffman E. Stigma Notes on the Management of Spoiled Identity. Englewood Cliffs, NJ: Prentice-Hall (1963).

32. Earnshaw VA, Chaudoir SR. From conceptualizing to measuring HIV stigma: a review of HIV stigma mechanism measures. AIDS Behav. (2009) 13:1160. doi: 10.1007/s10461-009-9593-3

33. Hatzenbuehler ML, Phelan JC, Link BG. Stigma as a fundamental cause of population health inequalities. Am J Public Health. (2013) 103:81321. doi: 10.2105/AJPH.2012.301069

34. Rael CT, Hampanda K. Understanding internalized HIV/AIDS-related stigmas in the Dominican Republic: a short report. AIDS Care. (2016) 28:319-24. doi: 10.1080/09540121.2015.1095277

35. Wood BR, Ballenger C, Stekler JD. Arguments for and against HIV selftesting. HIV/AIDS. (2014) 6:117. doi: 10.2147/HIV.S49083

36. Radcliffe J, Doty N, Hawkins LA, Gaskins CS, Beidas R, Rudy BJ. Stigma and sexual health risk in HIV-positive African American young men who have sex with men. AIDS Patient Care STDs. (2010) 24:4939. doi: 10.1089/apc.2010.0020

37. Smit PJ, Brady M, Carter M, Fernandes R, Lamore L, Meulbroek M, et al. HIV-related stigma within communities of gay men: a literature review. AIDS Care. (2012) 24:405-12. doi: 10.1080/09540121.2011.613910

38. Golub SA, Gamarel KE. The impact of anticipated HIV stigma on delays in HIV testing behaviors: findings from a community-based sample of men who have sex with men and transgender women in New York City. AIDS Patient Care STDs. (2013) 27:621-7. doi: 10.1089/apc.2013.0245

39. Gamarel KE, Nelson KM, Stephenson R, Rivera OJS, Chiaramonte D, Miller RL, et al. Anticipated HIV stigma and delays in regular HIV testing behaviors among sexually-active young gay, bisexual, and other men who have sex with men and transgender women. AIDS Behav. (2018) 22:52230. doi: 10.1007/s10461-017-2005-1

40. Okumu E, Jolly DH, Alston LM, Eley NT, Laws M, MacQueen KM. relationship between human immunodeficiency Virus (hiV) Knowledge, hiV-related stigma, and hiV Testing among Young Black adults in a southeastern city. Front Public Health. (2017) 5:47. doi: 10.3389/fpubh.2017.00047

41. Loutfy M, Tharao W, Logie C, Aden MA, Chambers LA, Wu $\mathrm{W}$, et al. Systematic review of stigma reducing interventions for African/Black diasporic women. J Int AIDS Soc. (2015) 18:19835. doi: 10.7448/IAS.18.1.19835

42. Stangl AL, Lloyd JK, Brady LM, Holland CE, Baral S. A systematic review of interventions to reduce HIV-related stigma and discrimination from 2002 to 2013: how far have we come? J Int AIDS Soc. (2013) 16:18734. doi: 10.7448/IAS.16.3.18734

43. Johnson AS, Hu X, Dean HD. Epidemiologic differences between nativeborn and foreign-born black people diagnosed with HIV infection in 33 US states, 2001-2007. Public Health Rep. (2010) 125(Suppl. 4): 61-9. doi: 10.1177/00333549101250S410

44. Hoffman S, Ransome Y, Adams-Skinner J, Leu CS, Terzian A. HIV/AIDS surveillance data for New York City West Indian-Born blacks: comparisons with other immigrant and US-born groups. Am J Public Health. (2012) 102:2129-34. doi: 10.2105/AJPH.2012.300672

45. Pachankis JE, Hatzenbuehler ML, Berg RC, Fernández-Dávila P, Mirandola M, Marcus U, et al. (2017). Anti-LGBT and anti-immigrant structural stigma: an intersectional analysis of sexual minority men's HIV risk when migrating to or within Europe. J Acquir Immune Def Syndrom. (1999) 76:356. doi: 10.1097/QAI.0000000000001519

46. Grieco E, Acosta Y, de la Cruz, P, Gambino C, Gryn T, Larsen L, et al. US Census Bureau American Community Survey 1103 Reports: The Foreign-Born Population in the United States: 2010. (2012). Retrieved from: https://www2. census.gov/library/publications/2012/acs/acs-19.pdf. (accessed October 9, 2019).

47. Steel J, Herlitz C, Matthews J, Snyder W, Mazzaferro K, Baum A, et al. Pre-migration trauma and HIV-risk behavior. Trans Psychiat. (2003) 40:91108. doi: $10.1177 / 1363461503040001006$

48. Beckwith CG, DeLong AK, Desjardins SF, Gillani F, Bazerman L, Mitty JA, et al. HIV infection in refugees: a case-control analysis of refugees in Rhode Island. Int J Infect Dis. (2009) 13:186-92. doi: 10.1016/j.ijid.2008.06.004

49. Nnaji C, Metzger N. Black is decidedly not just Black: a case study on HIV among African-born populations living in Massachusetts. Trotter Review. (2014) 22:7. Available online at: https://scholarworks.umb.edu/ trotter_review/vol22/iss1/7/. (accessed October 9, 2019).

50. Saint-Jean G, Dévieux J, Malow R, Tammara H, Carney K. Substance abuse, acculturation, and HIV risk among Caribbean-born immigrants in the United States. J Int Assoc Phys AIDS Care. (2011) 10:326-32. doi: 10.1177/1545109711401749

51. Wiewel EW, Torian LV, Hanna DB, Bocour A, Shepard CW. Foreign-born persons diagnosed with HIV: where are they from and where were they infected? AIDS Behav. (2015) 19:890-8. doi: 10.1007/s10461-014-0954-1

52. Singh GK, Hiatt RA. Trends and disparities in socioeconomic and behavioural characteristics, life expectancy, and cause-specific mortality of native-born and foreign-born populations in the United States, 1979-2003. Int J Epidemiol. (2006) 35:903-19. doi: 10.1093/ije/dyl089

53. Hoffman S, Beckford Jarrett ST, Kelvin EA, Wallace SA, Augenbraun M, Hogben M, et al. HIV and sexually transmitted infection risk behaviors and beliefs among Black West Indian immigrants and US-born Blacks. Am J Public Health. (2008) 98:2042-50. doi: 10.2105/AJPH.2006.106443

54. Levison JH, Regan S, Khan I, Freedberg KA. Foreign-born status as a predictor of engagement in HIV care in a large US metropolitan health system. AIDS Care. (2017) 29:244-51. doi: 10.1080/09540121.2016. 1210077

55. Wilson TE, Fraser-White M, Williams KM, Pinto A, Agbetor F, Camilien B, et al. Barbershop talk with brothers: using community-based participatory research to develop and pilot test a program to reduce HIV risk among Black heterosexual men. AIDS Educ Prevent. (2014) 26:38397. doi: 10.1521/aeap.2014.26.5.383 
56. Wilson TE, Gousse Y, Browne R, McFarlane, M.itchell S., Salifu M, Fraser M, et al. (2018). Barbershop talk with brothers: a cluster-randomized trial to increase condom use among heterosexual black men at risk for HIV infection. In: American Public Health Association Meeting. Atlanta GA.

57. Taylor TN, Joseph M, Henny KD, Pinto AR, Agbetor F, Camilien B, et al. Perceptions of HIV risk and explanations of sexual risk behavior offered by heterosexual black male barbershop patrons in Brooklyn, NY. J Health Disparit Res Pract. (2014) 7:1-25.

58. Ransome Y, Kawachi I, Braunstein S, Nash D. Structural inequalities drive late HIV diagnosis: the role of black racial concentration, income inequality, socioeconomic deprivation, and HIV testing. Health Place. (2016) 42:14858. doi: 10.1016/j.healthplace.2016.09.004

59. Ross J, Cunningham CO, Hanna DB. HIV outcomes among migrants from low-income and middle-income countries living in high-income countries: a review of recent evidence. Curr Opin Infect Dis. (2018) 31:2532. doi: 10.1097/QCO.0000000000000415

60. Rhodes SD, Leichliter JS, Sun CJ, Bloom FR. The HoMBReS and HoMBReS Por un Cambio interventions to reduce HIV disparities among immigrant Hispanic/Latino men. MMWR Suppl. (2016) 65:51. doi: 10.15585/mmwr.su6501a8

61. Cyrus E, Sheehan DM, Fennie K, Sanchez M, Dawson CT, Cameron $\mathrm{M}$, et al. Delayed Diagnosis of HIV among non-latino black caribbean immigrants in Florida 2000-2014. J Health Care Poor Underserv. (2018) 29:266. doi: 10.1353/hpu.2018.0019

62. Hammond WP, Matthews D, Mohottige D, Agyemang A, Corbie-Smith G. Masculinity, medical mistrust, and preventive health services delays among community-dwelling African-American men. J Gen Int Med. (2010) 25:1300-8. doi: 10.1007/s11606-010-1481-z

63. Arnett MJ, Thorpe RJ, Gaskin DJ, Bowie JV, LaVeist TA. Race, medical mistrust, and segregation in primary care as usual source of care: findings from the exploring health disparities in integrated communities study. $J$ Urban Health. (2016) 93:456-67. doi: 10.1007/s11524-016-0054-9

64. Ransome Y, Kawachi I, Dean LT. Neighborhood social capital in relation to late HIV diagnosis, linkage to HIV care, and HIV care engagement. AIDS Behav. (2017) 21:891-904. doi: 10.1007/s10461-0161581-9

65. Ku L, Matani S. Left out: immigrants' access to health care and insurance. Health Affairs. (2001) 20:247-56. doi: 10.1377/hlthaff.20.1.247

66. Bova C, Nnaji C, Woyah A, Duah A. HIV stigma, testing attitudes and health care access among African-born men living in the United States. J Immigr Minor Health. (2016) 18:187-93. doi: 10.1007/s10903-014-0136-2

67. United States Preventive Services Task Force. Human Immunodeficiency Virus (HIV) Infection: Screening. Rockville, MD: United States Preventive Services Task Force (2013). Retrieved from: https://www.uspreventiveservicestaskforce.org/Page/Document/

RecommendationStatementFinal/human-immunodeficiency-virus-hivinfection-screening1 (Accessed October 9, 2019).

68. National Institute on Minority Health and Health Disparities. NIMHD Research Framework. (2017). Retrieved from: https://www.nimhd.nih.gov/ about/overview/research-framework.html (accessed October 9, 2019).

69. Winston SE, Beckwith CG. The impact of removing the immigration ban on HIV-infected persons. AIDS Patient Care STDs. (2011) 25:70911. doi: 10.1089/apc.2011.0121

70. Centers for Disease Control and Prevention (CDC, and US Department of Health and Human Services. Medical examination of aliens-removal of human immunodeficiency virus (HIV) infection from definition of communicable disease of public health significance. Final rule. Fed Reg. (2009) 81:4191-206.

71. Thompson A. The immigration HIV exclusion: an ineffective means for promoting public health in a global age. Hous J Health L Pol'y. (2004) 5:145. Available online at: https://heinonline.org/HOL/LandingPage?handle=hein. journals/hhpol5\&div=9\&id=\&page $=($ accessed October 9,2019$)$.

72. Martinez O, Wu E, Sandfort T, Dodge B, Carballo-Dieguez A, Pinto R, et al. Evaluating the impact of immigration policies on health status among undocumented immigrants: a systematic review. J Immigr Minor Health. (2015) 17:947-70. doi: 10.1007/s10903-013-9968-4

73. Assistant Secretary for Planning and Evaluation. Summary of Immigrant Eligibility Restrictions Under Current Law. (2009). Available online at: https://aspe.hhs.gov/basic-report/summary-immigrant-eligibilityrestrictions- under-current-law. (accessed October 24, 2019).

74. Palmer BJ. The crossroads: Being black, immigrant, and undocumented in the era of \#BlackLivesMatter. Georgetown Journal of Law \& Modern Critical Race Perspectives (2017). Retrieved from: https://heinonline.org/ HOL/LandingPage?handle $=$ hein.journals $/$ gjmodco $9 \&$ div $=9 \& \mathrm{id}=\&$ page $=$ (accessed October 24, 2019).

75. Morgan-Trostle M, Zheng K, Lipscombe C. The State of Black Immigrants. Black Alliance for Just Immigration and NYU School of Law Immigrant Rights Clinic. (2016) Retrieved from: http://www.stateofblackimmigrants. com/assets/sobi-fullreport-jan22.pdf. (accessed October 24, 2019).

76. Golash-Boza T. The parallels between mass incarceration and mass deportation: an intersectional analysis of state repression. J World Syst Res. (2016) 22:484-509. doi: 10.5195/JWSR.2016.616

77. Armenta A, Alvarez I. Policing immigrants or policing immigration? Understanding local law enforcement participation in immigration control. Soc Compass. (2017) 11:e12453. doi: 10.1111/soc4.12453

78. Armenta A, Rosales R. Beyond the fear of deportation: understanding Unauthorized Immigrants' ambivalence toward the police. Am Behav Sci. (2019) 2019:0002764219835278. doi: 10.1177/0002764219835278

79. Ellis BH, Lincoln AK, Abdi SM, Nimmons EA, Issa O, Decker SH. "We All Have Stories" black muslim immigrants' experience with the police. Race Just. (2018) 2018:2153368718754638. doi: 10.1177/2153368718754638

80. Simmons WP, Alvord D, Valdez ES. Immigration enforcement, the racialization of legal status, and perceptions of the police. Du Bois Rev. (2018) 15:107-28. doi: 10.1017/S1742058X18000115

81. Galletly CL, Lechuga J, Glasman LR, DiFranceisco W, Broaddus MR, Dickson-Gomez JB, et al. HIV testing and mistaken beliefs about immigration laws. J Rac Ethnic Health Disparit. (2019) 6:668-75. doi: 10.1007/s40615-019-00565-0

82. Aung E, Blondell SJ, Durham J. Interventions for increasing HIV testing uptake in migrants: a systematic review of evidence. AIDS Behav. (2017) 21:2844-59. doi: 10.1007/s10461-017-1833-3

83. Kesler MA, Kaul R, Loutfy M, Myers T, Brunetta J, Remis RS, et al. Prosecution of non-disclosure of HIV status: potential impact on HIV testing and transmission among HIV-negative men who have sex with men. PLoS ONE. (2018) 13:e0193269. doi: 10.1371/journal.pone.0193269

84. Juan SC. The Impacts of HIV-Specific Criminal Laws on HIV, Serostatus Disclosure and Risk Behaviors and HIV Testing. Albany: State University of New York (2018).

85. Suleman S, Garber KD, Rutkow L. Xenophobia as a determinant of health: an integrative review. J Public Health Policy. (2018) 39:40723. doi: 10.1057/s41271-018-0140-1

86. Fouron GE. Race, blood, disease and citizenship: the making of the Haitian-Americans and the Haitian immigrants into 'the others' during the 1980s-1990s AIDS crisis. Identities. (2013) 20:705-19. doi: 10.1080/1070289X.2013.828624

87. Farmer P. AIDS and Accusation: Haiti and the Geography of Blame. 2nd edn. Berkeley University of California Press (2006).

88. Brodwin P. Medicine and Morality in Haiti: The Contest for Healing Power. Cambridge: Cambridge University Press; Cambridge Studies in Medical Anthropology (1996). doi: 10.1017/CBO9780511613128

89. Farmer P. Sending sickness: sorcery, politics, and changing concepts of AIDS in rural Haiti. Med Anthropol Quart. (1990) 4:6-27. doi: 10.1525/maq.1990.4.1.02a00020

90. Gemmill A, Catalano R, Casey JA, Karasek D, Alcalá HE, Elser $\mathrm{H}$, et al. Association of preterm births among US latina women with the 2016 presidential election. JAMA Network Open. (2019) 2:e197084. doi: 10.1001/jamanetworkopen.2019.7084

91. Morey BN. Mechanisms by which anti-immigrant stigma exacerbates racial/ethnic health disparities. Am J Public Health. (2018) 108:4603. doi: 10.2105/AJPH.2017.304266

92. Dworkin SL, Fleming PJ, Colvin CJ. The promises and limitations of gender-transformative health programming with men: critical reflections from the field. Cult Health Sexual. (2015) 17(Suppl. 2): 28-143. doi: 10.1080/13691058.2015.1035751

93. Knight $\mathrm{R}$, Shoveller JA, Oliffe JL, Gilbert M, Goldenberg S. Heteronormativity hurts everyone: Experiences of young men and clinicians 
with sexually transmitted infection/HIV testing in British Columbia, Canada. Health. (2013) 17:441-59. doi: 10.1177/1363459312464071

94. Sileo KM, Fielding-Miller R, Dworkin SL, Fleming PJ. What role do masculine norms play in men's HIV testing in sub-Saharan Africa?: a scoping review. AIDS Behav. (2018) 22:2468-79. doi: 10.1007/s10461-018-2160-z

95. Mburu G, Ram M, Siu G, Bitira D, Skovdal M, Holland P. Intersectionality of HIV stigma and masculinity in eastern Uganda: implications for involving men in HIV programmes. BMC Public Health. (2014) 14:1061. doi: 10.1186/1471-2458-14-1061

96. Janzen JM. AIDS and STDs in Africa: bridging the gap between traditional healing and modem medicine. Am Ethnol. (1997) 24:48990. doi: 10.1525/ae.1997.24.2.489

97. Ingstad B. The cultural construction of AIDS and its consequences for prevention in Botswana. Med Anthropol Quart. (1990) 4:28-40. doi: 10.1525/maq.1990.4.1.02a00030

98. Frye V, Paige MQ, Gordon S, Matthews D, Musgrave G, Kornegay M, et al. Developing a community-level anti-HIV/AIDS stigma and homophobia intervention in new York city: the project CHHANGE model. Eval Program Plann. (2017) 63:45-53. doi: 10.1016/j.evalprogplan.2017.03.004

99. Archibald C. HIV/AIDS-associated stigma among Afro-Caribbean people living in the United States. Arch Psychiat Nurs. (2010) 24:362-4. doi: 10.1016/j.apnu.2010.04.004

100. Airall-Simon G. HIV related Stigma in Antigua, and Barbuda. Minneapolis, MN; Walden University (2014).

101. Anderson M, Elam G, Gerver S, Solarin I, Fenton K, Easterbrook P. HIV/AIDS-related stigma and discrimination: accounts of HIV-positive Caribbean people in the United Kingdom. Soc Sci Med. (2008) 67:7908. doi: 10.1016/j.socscimed.2008.05.003

102. Anderson M, Elam G, Solarin I, Gerver S, Fenton K, Easterbrook P. Coping with HIV: caribbean people in the United Kingdom. Qual Health Res. (2009) 19:1060-75. doi: 10.1177/1049732309341191

103. Norman LR, Carr R, Jimenez J. Sexual stigma and sympathy: Attitudes toward persons living with HIV in Jamaica. Cul Health Sexual. (2006) 8:423-33. doi: 10.1080/13691050600855748

104. Crosby RA, Milhausen RR, Sanders SA, Graham CA, Yarber WL. Condom use errors and problems: a study of high-risk young Black men residing in three Southern US cities. Int J STD and AIDS. (2014) 25:9438. doi: $10.1177 / 0956462414526707$

105. Eaton LA, Driffin DD, Kegler C, Smith H, Conway-Washington C, White $\mathrm{D}$, et al. The role of stigma and medical mistrust in the routine health care engagement of black men who have sex with men. Am J Public Health. (2015) 105:e75-82. doi: 10.2105/AJPH.2014.302322

106. Ford CL, Wallace SP, Newman PA, Lee SJ, Cunningham WE. Belief in AIDSrelated conspiracy theories and mistrust in the government: relationship with HIV testing among at-risk older adults. Gerontologist. (2013) 53:97384. doi: 10.1093/geront/gns 192

107. Graham JL, Grimes RM, Slomka J, Ross M, Hwang LY, Giordano TP. The role of trust in delayed HIV diagnosis in a diverse, urban population. AIDS Behav. (2013) 17:266-73. doi: 10.1007/s10461-011-0114-9

108. Read JNG, Emerson MO. Racial context, black immigration and the US black/white health disparity. Soc Forces. (2005) 84:181-99. doi: 10.1353/sof.2005.0120

109. Read JNG, Emerson MO, Tarlov A. Implications of black immigrant health for US racial disparities in health. J Immigrant Health. (2005) 7:20512. doi: 10.1007/s10903-005-3677-6

110. Hamilton TG, Hummer RA. Immigration and the health of US black adults: does country of origin matter? Soc Sci Med. (2011) 73:155160. doi: 10.1016/j.socscimed.2011.07.026

111. Tuggle AC, Cohen JH, Crews DE. Stress, migration, and allostatic load: a model based on Mexican migrants in Columbus, Ohio. J Physiol Anthropol. (2018) 37:28. doi: 10.1186/s40101-018-0188-4

112. Castañeda H, Holmes SM, Madrigal DS, Young MED, Beyeler N, Quesada J. Immigration as a social determinant of health. Ann Rev Public Health. (2015) 36:375-92. doi: 10.1146/annurev-publhealth-032013-182419

113. Viruell-Fuentes EA, Miranda PY, Abdulrahim S. More than culture: structural racism, intersectionality theory, and immigrant health. Soc Sci Med. (2012) 75:2099-106. doi: 10.1016/j.socscimed.2011.12.037
114. Martinez-Donate AP, Zhang X, Rangel MG, Hovell MF, Gonzalez-Fagoaga JE, Magis-Rodriguez C, et al. Does acculturative stress influence immigrant sexual HIV risk and HIV testing behavior? evidence from a survey of male mexican migrants. J Rac Ethnic Health Disparities. (2018) 5:798807. doi: 10.1007/s40615-017-0425-2

115. Olawore O, Tobian AA, Kagaayi J, Bazaale JM, Nantume B, Kigozi G, et al. Migration and risk of HIV acquisition in Rakai, Uganda: a population-based cohort study. Lancet HIV. (2018) 5:e181-9. doi: 10.1016/S2352-3018(18)30009-2

116. Nieves-Lugo K, Barnett A, Pinho V, Reisen C, Poppen P, Zea MC. Sexual migration and HIV risk in a sample of Brazilian, Colombian and Dominican immigrant MSM living in New York City. J Immigr Minor Health. (2019) 21:115-22. doi: 10.1007/s10903-018-0716-7

117. Greenaway C, Castelli F. Infectious diseases at different stages of migration: an expert review. J Travel Med. (2019) 26:taz007. doi: 10.1093/jtm/taz007

118. Mihan R, Kerr J, Maticka-Tyndale E, ACBY Team HIV-related stigma among African, Caribbean, and Black youth in Windsor, Ontario. AIDS Care. (2016) 28:758-63. doi: 10.1080/09540121.2016.1158397

119. Du H, Li X. Acculturation and HIV-related sexual behaviours among international migrants: a systematic review and meta-analysis. Health Psychol Rev. (2015) 9:103-22. doi: 10.1080/17437199.2013.840952

120. Martinez I, Kershaw TS, Keene D, Perez-Escamilla R, Lewis JB, Tobin JN, et al. Acculturation and syndemic risk: longitudinal evaluation of risk factors among pregnant Latina adolescents in new York City. Ann Behav Med. (2017) 52:42-52. doi: 10.1007/s12160-017-9924-y

121. Jardin C, Garey L, Sharp C, Zvolensky MJ. Acculturative stress and risky sexual behavior: the roles of sexual compulsivity and negative affect. Behav Modific. (2016) 40:97-119. doi: 10.1177/0145445515613331

122. Yang N, Xu Y, Chen X, Yu B, Yan H, Li S. Acculturative stress, poor mental health and condom-use intention among international students in China. Health Educ J. (2018) 77:142-55. doi: 10.1177/0017896917739443

123. Erving CL, Hills O. Neighborhood social integration and psychological wellbeing among African Americans and Afro-Caribbeans. Race Soc Problems. (2019) 2019:1-16. doi: 10.1007/s12552-019-09258-z

124. Feldmeyer B, Madero-Hernandez A, Rojas-Gaona CE, Sabon LC. Immigration, collective efficacy, social ties, and violence: Unpacking the mediating mechanisms in immigration effects on neighborhood-level violence. Race Just. (2019) 9:123-50. doi: 10.1177/2153368717690563

125. Blondell SJ, Kitter B, Griffin MP, Durham J. Barriers and facilitators to HIV testing in migrants in high-income countries: a systematic review. AIDS Behav. (2015) 19:2012-24. doi: 10.1007/s10461-015-1095-x

126. Evangeli M, Pady K, Wroe AL. Which psychological factors are related to HIV testing? A quantitative systematic review of global studies. AIDS Behav. (2016) 20:880-918. doi: 10.1007/s10461-015-1246-0

127. Pitkin Derose K, Bahney BW, Lurie N, Escarce JJ. Immigrants and health care access, quality, and cost. Med Care Res Rev. (2009) 66:355408. doi: 10.1177/1077558708330425

128. Simbiri KOA, Hausman A, Wadenya RO, Lidicker J. Access impediments to health care and social services between Anglophone and Francophone African immigrants living in Philadelphia with respect to HIV/AIDS. $J$ Immigr Minor Health. (2010) 12:569-79. doi: 10.1007/s10903-009-9229-8

129. Othieno J. Understanding how contextual realities affect African born immigrants and refugees living with HIV in accessing care in the Twin Cities. J Health Care Poor Underser. (2007) 18:170-88. doi: 10.1353/hpu.2007.0085

130. Lepore SJ, Nair RG, Davis SN, Wolf RL, Basch CE, Thomas N, et al. Patient and physician factors associated with undisclosed prostate cancer screening in a sample of predominantly immigrant black men. J Immigr Minor Health. (2017) 19:1343-50. doi: 10.1007/s10903-016-0468-1

131. Rhodes SD, Mann L, Simán FM, Song E, Alonzo J, Downs M, et al. The impact of local immigration enforcement policies on the health of immigrant Hispanics/Latinos in the United States. Am J Public Health. (2015) 105:32937. doi: 10.2105/AJPH.2014.302218

132. Ansa B, White S, Chung Y, Smith S. Trends in HIV testing among adults in Georgia: analysis of the 2011-2015 BRFSS data. Int J Environ Res Public Health. (2016) 13:1126. doi: 10.3390/ijerph13111126

133. Barskey AE, Surendera Babu A, Hernandez A, Espinoza L. Patterns and trends of newly diagnosed HIV infections among adults and adolescents in 
correctional and noncorrectional facilities, United States, 2008-2011. Am J Public Health. (2016) 106:103-9. doi: 10.2105/AJPH.2015.302868

134. Wafula EG, Snipes SA. Barriers to health care access faced by black immigrants in the US: theoretical considerations and recommendations. $J$ Immigr Minor Health. (2014) 16:689-98. doi: 10.1007/s10903-013-9898-1

135. Crenshaw K. Intersectionality and identity politics: learning from violence against women of color. In: Shanley ML, Narayan U, editors. Reconstructing Political Theory: Feminist Perspectives. Pennsylvania State University Press (1997). p. 178-93.

136. Crenshaw K. Demarginalizing the Intersection of Race and Sex: A Black Feminist Critique of Antidiscrimination Doctrine, Feminist Theory and Antiracist Politics. University of Chicago Legal Forum (1989). p. 139. Retrieved from: https://chicagounbound.uchicago.edu/uclf/vol1989/iss1/8 (accessed October 24, 2019).

137. Berger MT. Workable Sisterhood: The Political Journey of Stigmatized Women With HIV/AIDS. Princeton, NJ: Princeton University Press (2010).

138. Earnshaw VA, Smith LR, Cunningham CO, Copenhaver MM. Intersectionality of internalized HIV stigma and internalized substance use stigma: Implications for depressive symptoms. J Health Psychol. (2015) 20:1083-9. doi: 10.1177/1359105313507964

139. Turan B, Hatcher AM, Weiser SD, Johnson MO, Rice WS, Turan JM. Framing mechanisms linking HIV-related stigma, adherence to treatment, and health outcomes. Am J Public Health. (2017) 107:8639. doi: 10.2105/AJPH.2017.303744

140. Jackson-Best F, Edwards N. Stigma and intersectionality: a systematic review of systematic reviews across HIV/AIDS, mental illness, and physical disability. BMC Public Health. (2018) 18:919. doi: 10.1186/s12889-018-5861-3

141. Earnshaw VA, Reed NM, Watson RJ, Maksut JL, Allen AM, Eaton LA. Intersectional internalized stigma among Black gay and bisexual men: a longitudinal analysis spanning HIV/sexually transmitted infection diagnosis. J Health Psychol. (2019) 2019:1359105318820101. doi: 10.1177/1359105318820101

142. Sun S, Crooks N, Kemnitz R, Westergaard RP. Re-entry experiences of Black men living with HIV/AIDS after release from prison: Intersectionality and implications for care. Soc Sci Med. (2018) 211:78-86. doi: 10.1016/j.socscimed.2018.06.003

143. Bowleg L. "Once you've blended the cake, you can't take the parts back to the main ingredients": black gay and bisexual men's descriptions and experiences of intersectionality. Sex Roles. (2013) 68:754-67. doi: 10.1007/s11199-012-0152-4

144. Bowleg L, del Rio-Gonzalez AM, Holt SL, Pérez C, Massie JS, Mandell $\mathrm{JE}$, et al. Intersectional epistemologies of ignorance: how behavioral and social science research shapes what we know, think we know, and don't know about US Black men's sexualities. J Sex Res. (2017) 54:577603. doi: 10.1080/00224499.2017.1295300

145. Turan JM, Elafros MA, Logie CH, Banik S, Turan B, Crockett KB, et al. Challenges and opportunities in examining and addressing intersectional stigma and health. BMC Med. (2019) 17:7. doi: 10.1186/s12916-018-1246-9

146. Lee JJ, Yu G. HIV testing, risk behaviors, and fear: a comparison of documented and undocumented Latino immigrants. AIDS Behav. (2018) 23:336-46. doi: 10.1007/s10461-018-2251-x

147. Ford CL, Daniel M, Earp JAL, Kaufman JS, Golin CE, Miller WC. Perceived everyday racism, residential segregation, and HIV testing among patients at a sexually transmitted disease clinic. Am J Public Health. (2009) 99:S13743. doi: 10.2105/AJPH.2007.120865

148. Irvin R, Wilton L, Scott H, Beauchamp G, Wang L, Betancourt J, et al. A study of perceived racial discrimination in Black men who have sex with men (MSM) and its association with healthcare utilization and HIV testing. AIDS Behav. (2014) 18:1272-8. doi: 10.1007/s10461-014-0734-y

149. Cahill S, Taylor SW, Elsesser SA, Mena L, Hickson D, Mayer KH. Stigma, medical mistrust, and perceived racism may affect PrEP awareness and uptake in black compared to white gay and bisexual men in Jackson, Mississippi and Boston, Massachusetts. AIDS Care. (2017) 29:13518. doi: 10.1080/09540121.2017.1300633

150. Boarts JM, Bogart LM, Tabak MA, Armelie AP, Delahanty DL. Relationship of race-, sexual orientation-, and HIV-related discrimination with adherence to HIV treatment: a pilot study. J Behav Med. (2008) 31:445-51. doi: 10.1007/s10865-008-9169-0

151. Eaton LA, Kalichman SC, Price D, Finneran S, Allen A, Maksut J. Stigma and conspiracy beliefs related to pre-exposure prophylaxis (PrEP) and interest in using PrEP among black and white men and transgender women who have sex with men. AIDS Behav. (2017) 21:123646. doi: 10.1007/s10461-017-1690-0

152. Winkler MB. Executive Order Protecting the Nation from Foreign Terrorist Entry into the United States: Violating First Amendment Rights or Altering Constitutional Provisions Granting Foreign Policy Powers to the President. TM Cooley L Rev (2017). Available online at: https://heinonline.org/HOL/ LandingPage handle $=$ hein.journals/tmclr34\&div=8\&id $=$ \&page $=$. (accessed October 9, 2019).

153. Pierce S, Selee A. Immigration Under Trump: A Review of Policy Shifts in the Year Since the Election. Washington DC: Migration Policy Institute (2017).

154. Morey BN, Gee GC, Muennig P, Hatzenbuehler ML. Community-level prejudice and mortality among immigrant groups. Soc Sci Med. (2018) 199:56-66. doi: 10.1016/j.socscimed.2017.04.020

155. Abdelkader E. When Islamophobia turns Violent: The 2016 US Presidential Elections. The Bridge Initiative, Georgetown University (2016). Retrieved from: https://ssrn.com/abstract=2779201 (accessed October 9, 2019).

156. Rushin S, Edwards GS. The effect of president Trump's election on hate crimes. Available at SSRN. (2018) 2018:3102652. doi: 10.2139/ssrn.3102652

157. Siegel A, Nikitin E, Barberá P, Sterling J, Pullen B, Bonneau R, et al. Trumping Hate on Twitter? Online Hate in the 2016 US Election and Its Aftermath (2019). Retrieved from: https://smappnyu.org/wpcontent/uploads/2019/04/US_Election_Hate_Speech_2019_03_website.pdf (accessed October 9, 2019).

158. Müller K, Schwarz C. Making America hate again? Twitter and Hate Crime Under Trump. Twitter Hate Crime Under Trump. (2018). doi: 10.2139/ssrn.3149103

159. Veldhuis CB, Drabble L, Riggle ED, Wootton AR, Hughes TL. "We Won't Go Back Into the Closet Now Without One Hell of a Fight": Effects of the 2016 Presidential Election on Sexual Minority Women's and Gender Minorities' Stigma-Related Concerns. Sexual Res Soc Policy, Vol. 15. Basel: Springer Nature Switzerland (2018). p. 12-24 (accessed October 9, 2019).

160. Veldhuis CB, Drabble L, Riggle ED, Wootton AR, Hughes TL. "I Fear for My Safety, but Want to Show Bravery for Others": violence and discrimination concerns among transgender and gender-nonconforming individuals after the 2016 presidential election. Violence Gend. (2018) 5:2636. doi: 10.1089/vio.2017.0032

161. Gonzalez KA, Ramirez JL, Galupo MP. Increase in GLBTQ minority stress following the 2016 US presidential election. J GLBT Family Stud. (2018) 14:130-51. doi: 10.1080/1550428X.2017.1420849

162. McManus HD, Cullen FT, Jonson CL, Burton AL, Burton Jr VS. Will black lives matter to the police? African Americans' Concerns about Trump's Presidency. Victims Offen. (2019) 14:1040-62. doi: 10.1080/15564886.2019.1671288

163. Powell KJ. "The Year of the Ballot or the Bullet": a discussion of race, revolution, and the 2016 election. Women's Stud Commun. (2016) 39:3704. doi: 10.1080/07491409.2016.1227187

164. Chernega J. Black lives matter: racialised policing in the United States. Comparat Am Stud Int J. (2016) 14:23445. doi: 10.1080/14775700.2016.1267322

165. Drakulich K, Hagan J, Johnson D, Wozniak KH. Race, justice, policing, and the 2016 American presidential election. Du Bois Rev Soc Sci Res Race. (2017) 14:7-33. doi: 10.1017/S1742058X1600031X

166. Krieger N, Huynh M, Li W, Waterman PD, Van Wye G. Severe sociopolitical stressors and preterm births in New York City: 1 September 2015 to 31 August 2017. J Epidemiol Community Health. (2018) 72:114752. doi: 10.1136/jech-2018-211077

167. Stanhope KK, Hogue CR, Suglia SF, Leon JS, Kramer MR. Restrictive subfederal immigration policy climates and very preterm birth risk among USborn and foreign-born Hispanic mothers in the United States, 2005-2016. Health Place. (2019) 60:102209. doi: 10.1016/j.healthplace.2019.102209

168. Treichler PA. AIDS, homophobia, and biomedical discourse: an epidemic of signification. October. (1987) 43:31-70. doi: 10.2307/3397564 
169. Arnold EA, Rebchook GM, Kegeles SM. 'Triply cursed': racism, homophobia and HIV-related stigma are barriers to regular HIV testing, treatment adherence and disclosure among young Black gay men. Cult Health Sexual. (2014) 16:710-22. doi: 10.1080/13691058.2014.905706

170. Frye V, Wilton L, Hirshfield S, Chiasson MA, Lucy D, Usher D, All About Me Study Team. Preferences for HIV test characteristics among young, Black Men Who Have Sex With Men (MSM) and transgender women: implications for consistent HIV testing. PLoS ONE. (2018) 13:e0192936. doi: 10.1371/journal.pone.0192936

171. Calabrese SK, Earnshaw VA, Krakower DS, Underhill K, Vincent W, Magnus M, et al. A closer look at racism and heterosexism in medical students' clinical decision-making related to HIV pre-exposure prophylaxis (PrEP): implications for PrEP education. AIDS Behav. (2018) 22:112238. doi: $10.1007 / \mathrm{s} 10461-017-1979-\mathrm{z}$

172. Haile R, Rowell-Cunsolo TL, Parker EA, Padilla MB, Hansen NB. An empirical test of racial/ethnic differences in perceived racism and affiliation with the gay community: Implications for HIV risk. J Soc Issues. (2014) 70:342-59. doi: 10.1111/josi.12063

173. Haile R, Rowell-Cunsolo TL, Parker EA, Padilla MB, Hansen NB. An empirical test of racial/ethnic differences in perceived racism and affiliation with the gay community: Implications for HIV risk. J Soc Issues. (2014) 70:342-359. doi: 10.1111/josi.1206300

174. Bogart LM, Landrine H, Galvan FH, Wagner GJ, Klein DJ. Perceived discrimination and physical health among HIV-positive Black and Latino men who have sex with men. AIDS Behav. (2013) 17:143141. doi: $10.1007 /$ s10461-012-0397-5

175. Joint United Nations Programme on HIV/AIDS (UNAIDS). UNAIDS Report on the Global AIDS Epidemic 2010. Geneva: Joint United Nations Programme on HIV/AIDS (UNAIDS) (2011).

176. Cook JE, Purdie-Vaughns V, Meyer IH, Busch JT. Intervening within and across levels: a multilevel approach to stigma and public health. Soc Sci Med. (2014) 103:101-9. doi: 10.1016/j.socscimed.2013.09.023

177. Operario D, Smith CD, Arnold E, Kegeles S. The Bruthas Project: evaluation of a community-based HIV prevention intervention for African American men who have sex with men and women. AIDS Educ Prevent. (2010) 22:37-48. doi: 10.1521/aeap.2010.22.1.37

178. Klein CH, Kuhn T, Huxley D, Kennel J, Withers E, Lomonaco CG. Preliminary findings of a technology-delivered sexual health promotion program for black men who have sex with men: quasiexperimental outcome study. JMIR Public Health Surveill. (2017) 3:e78. doi: 10.2196/publichealth.7933

179. Stein R, Shapatava E, Williams W, Griffin T, Bell K, Lyons B, et al. Reduced sexual risk behaviors among young Men of color Who have Sex with Men: findings from the community-based organization behavioral outcomes of many Men, many voices (CBOP-3MV) project. Prevent Sci. (2015) 16:114758. doi: 10.1007/s11121-015-0565-8

180. Nelson LE, Walker JNJ, DuBois SN, Giwa S. Your blues ain't like mine: considering integrative antiracism in HIV prevention research with black men who have sex with men in $\mathrm{C}$ anada and the $\mathrm{U}$ nited $\mathrm{S}$ tates. Nurs Inquiry. (2014) 21:270-82. doi: 10.1111/nin.12055

181. Hightow-Weidman LB, Pike E, Fowler B, Matthews DM, Kibe J, McCoy R, et al. HealthMpowerment. org: feasibility and acceptability of delivering an internet intervention to young Black men who have sex with men. AIDS Care. (2012) 24:910-20. doi: 10.1080/09540121.2011.647677

182. Huang E, Marlin RW, Young SD, Medline A, Klausner JD. Using Grindr, a smartphone social-networking application, to increase HIV self-testing among Black and Latino men who have sex with men in Los Angeles, 2014. AIDS Educ Prevent. (2016) 28:341-50. doi: 10.1521/aeap.2016.28.4.341

183. Harper GW, Fernandez IM, Bruce D, Hosek SG, Jacobs RJ, Adolescent Medicine Trials Network for HIV/AIDS, et al. The role of multiple identities in adherence to medical appointments among gay/bisexual male adolescents living with HIV. AIDS Behav. (2013) 17:213-23. doi: 10.1007/s10461-011-0071-3

184. Jamil MS, Prestage G, Fairley CK, Grulich AE, Smith KS, Chen $\mathrm{M}$, et al. Effect of availability of HIV self-testing on HIV testing frequency in gay and bisexual men at high risk of infection (FORTH): a waiting-list randomised controlled trial. Lancet HIV. (2017) 4:e241e250. doi: 10.1016/S2352-3018(17)30023-1
185. Hall EW, Ricca AV, Khosropour CM, Sullivan PS. Capturing HIV incidence among MSM through at-home and self-reported facility-based testing. J Acquir Immune Def Syndrom. (2017) 75:e142. doi: 10.1097/QAI.0000000000001338

186. Witzel TC, Weatherburn P, Burns FM, Johnson CC, Figueroa C, Rodger AJ. Consolidating emerging evidence surrounding HIVST and HIVSS: a rapid systematic mapping protocol. Syst Rev. (2017) 6:72. doi: 10.1186/s13643-017-0452-4

187. Ahmed-Little Y, Bothra V, Cordwell D, Freeman Powell D, Ellis D, Klapper P, et al. Attitudes towards HIV testing via home-sampling kits ordered online (RUClear pilots 2011-12). J Public Health. (2016) 38:58590. doi: 10.1093/pubmed/fdv075

188. Curlin ME, Gvetadze R, Leelawiwat W, Martin M, Rose C, Niska RW, et al. Analysis of false-negative human immunodeficiency virus rapid tests performed on oral fluid in 3 international clinical research studies. Clin Infect Dis. (2017) 64:1663-9. doi: 10.1093/cid/cix228

189. Spotonsciences.com. HemaSpot ${ }^{\mathrm{TM}}$-HF Blood Collection Device. (2017) Retrieved from: http://www.spotonsciences.com/hemaspot/. (accessed October 24, 2019).

190. van Loo IH, Dukers-Muijrers NH, Heuts R, van der Sande MA, Hoebe CJ. Screening for HIV, hepatitis B and syphilis on dried blood spots: a promising method to better reach hidden highrisk populations with self-collected sampling. PLoS ONE. (2017) 12:e0186722. doi: 10.1371/journal.pone.0186722

191. Kania D, Bekale AM, Nagot N, Mondain AM, Ottomani L, Meda N, et al. Combining rapid diagnostic tests and dried blood spot assays for pointof-care testing of human immunodeficiency virus, hepatitis B and hepatitis C infections in Burkina Faso, West Africa. Clin Microbiol Infect. (2013) 19:E533-41. doi: 10.1111/1469-0691.12292

192. Hirshfield S, Teran RA, Downing MJ Jr, Chiasson MA, Tieu HV, Dize L, Gaydos CA. Quantification of HIV-1 RNA among men who have sex with men using an at-home self-collected dried blood spot specimen: feasibility study. JMIR Public Health Surveill. (2018) 4:e10847. doi: 10.2196/ 10847

193. Armstrong B, Kalmuss D, Franks M, Hecker G, Bell D. Creating teachable moments: a clinic-based intervention to improve young men's sexual health. Am J Men's Health. (2010) 4:135-44. doi: 10.1177/1557988309331796

194. Craw JA, Gardner LI, Marks G, Rapp RC, Bosshart J, Duffus WA, et al. Brief strengths-based case management promotes entry into HIV medical care: results of the antiretroviral treatment access study-II. JAIDS J Acquir Immune Defic Syndromes. (2008) 47:597-606. doi: 10.1097/QAI.0b013e3181684c51

195. Sebesta DS, Marx R, Liu Y. HIV prevention case management in San Francisco: barriers to successful implementation. AIDS Care. (2006) 18:345-55. doi: 10.1080/09540120500200641

196. Desai M, Woodhall SC, Nardone A, Burns F, Mercey D, Gilson R. Active recall to increase HIV and STI testing: a systematic review. Sex Transm Infect. (2015) 91:314-23. doi: 10.1136/sextrans-2014-051930

197. Luque JS, Ross L, Gwede CK. Qualitative systematic review of barberadministered health education, promotion, screening and outreach programs in African-American communities. J Community Health. (2014) 39:181-90. doi: 10.1007/s10900-013-9744-3

198. Linnan LA, D'Angelo H, Harrington CB. A literature synthesis of health promotion research in salons and barbershops. Am J Prev Med. (2014) 47:77-85. doi: 10.1016/j.amepre.2014.02.007

199. Wilson TE, Gousse Y, Joseph MA, Browne RC, Camilien B, McFarlane D, et al. HIV prevention for black heterosexual men: the barbershop talk with brothers cluster randomized trial. Am J Public Health. (2019) 109:11317. doi: 10.2105/AJPH.2019.305121

200. Services C.f.M.,M. Decision Memo for Screening for the Human Immunodeficiency Virus (HIV) Infection (CAG-00409R). (2015). Available online at: https://www.cms.gov/medicare-coverage-database/details/ncadecision-memo.aspx?NCAId=276 (accessed October 9, 2019).

201. Services U.S.D.o.H.a.H. Statement on FY2020 Budget Proposal for End the HIV Epidemic in America. Available online at: (accessed October 15, 2019).

202. AIDS United. Ending the HIV Epidemic in the United States: A Roadmap for Federal Action. (2019). Available online at: https://www.aidsunited.org/data/ files/Site_18/Policy/Ending_the__HIV_Epidemic_U.S._Roadmap_ for_Federal_\%20Action_FINAL.pdf (accessed October 9, 2019). 
203. Demko P. How Healthcare's Washington Lobbying Machine Gets the Job Done. (2014). Available online at: https://www.modernhealthcare.com/ article/20141004/MAGAZINE/310049987/how-healthcare-s-washingtonlobbying-machine-gets-the-job-done

204. Friedman AL, Kachur RE, Noar SM, McFarlane M. Health communication and social marketing campaigns for sexually transmitted disease prevention and control: what is the evidence of their effectiveness? Sexual Trans Dis. (2016) 43:S83-101. doi: 10.1097/OLQ.00000000000 00286

205. Sanders RA, Ellen JM. Structural Interventions With an Emphasis on Poverty and Racism in African Americans and HIV/AIDS. Springer (2010). p. 255-70. doi: 10.1007/978-0-387-78321-5_14

206. Pichon L, Powell T. Review of HIV testing efforts in historically black churches. Int J Environ Res Public Health. (2015) 12:601626. doi: 10.3390/ijerph120606016

207. Frye V, Paige MQ, Gordon S, Matthews D, Musgrave G, Greene E, et al. Impact of a community-level intervention on HIV stigma, homophobia and HIV testing in New York City: Results from project CHHANGE. Stigma Health. (2019) 4:72. doi: 10.1037/sah0000109

208. McNeil DG Jr. New York, NY: The New York Times (2018). https://www. nytimes.com/2018/03/26/health/grindr-hiv-test-reminder.html

209. Senn TE, Braksmajer A, Coury-Doniger P, Urban MA, Carey MP. Mobile technology use and desired technology-based intervention characteristics among HIV+ Black men who have sex with men. AIDS Care. (2017) 29:423-7. doi: 10.1080/09540121.2016.1220479
210. Levy ME, Watson CC, Wilton L, Criss V, Kuo I, Glick SN, et al. Acceptability of a mobile smartphone application intervention to improve access to HIV prevention and care services for black men who have sex with men in the District of Columbia. Digital Cult Educ. (2015) 7:169.

211. Archibald CM, Newman D. Pilot testing HIV prevention in an Afro Caribbean faith-based community. ABNF J. (2015) 26:43-9.

212. Fleming PJ, Dworkin SL. The importance of masculinity and gender norms for understanding institutional responses to HIV testing and treatment strategies. AIDS. (2016) 30:157. doi: 10.1097/QAD.0000000000000899

213. Dworkin SL, Treves-Kagan S, Lippman SA. Gender-transformative interventions to reduce HIV risks and violence with heterosexuallyactive men: a review of the global evidence. AIDS Behav. (2013) 17:2845-63. doi: 10.1007/s10461-013-0565-2

Conflict of Interest: The authors declare that the research was conducted in the absence of any commercial or financial relationships that could be construed as a potential conflict of interest.

Copyright (c) 2020 Taylor, DeHovitz and Hirshfield. This is an open-access article distributed under the terms of the Creative Commons Attribution License (CC BY). The use, distribution or reproduction in other forums is permitted, provided the original author(s) and the copyright owner(s) are credited and that the original publication in this journal is cited, in accordance with accepted academic practice. No use, distribution or reproduction is permitted which does not comply with these terms. 